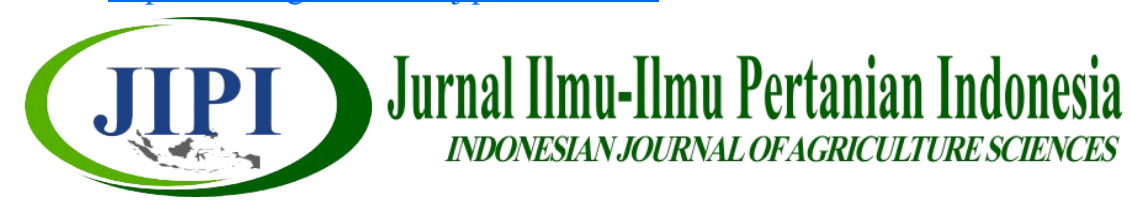

\title{
PENGARUH JARAK TANAM DAN FREKUENSI PENYIANGAN TERHADAP PERTUMBUHAN, HASIL KACANG TANAH DAN POPULASI GULMA
}

\author{
Dina Yulianti Sisca Vera ${ }^{1}$, Edhi Turmudi ${ }^{1 *}$, Eko Suprijono ${ }^{1}$ \\ ${ }^{1}$ Program Studi Agroekoteknologi, Fakultas Pertanian Universitas Bengkulu \\ * Corresponding Author: edhiturmudi@unib.ac.id
}

\begin{abstract}
[THE EFFECT OF PLANTING DISTANCE AND WEDDING FREQUENCY ON GROWTH, YIELD OF PEANUT AND WEED POPULATION]. This study was aimed to determine planting distance and frequency of weeding which gives the highest growth and yield of peanuts. Peanut plants were planted in the Experimental Field of the Faculty of Agriculture, Bengkulu University from October to December 2018. The study was arranged in a Complete Randomized Block Design (RCBD) with 2 factors and 3 replications. The first factor is the planting distance of $40 \mathrm{~cm} \times 20 \mathrm{~cm} ; 40 \mathrm{~cm} \times 30 \mathrm{~cm}$ and $40 \mathrm{~cm} \times 40 \mathrm{~cm}$. The second factor is the frequency of weeding consisting of no weeding, $1 \mathrm{x}$ weeding (age $2 \mathrm{WAP}$ ), $2 \mathrm{x}$ weeding ( 2 and $4 \mathrm{WAP})$, and $3 \mathrm{x}$ weeding $(2,4$, and 6 WAP). The results showed that the interaction between the spacing of $40 \mathrm{~cm}$ x $40 \mathrm{~cm}$ and $2 \times$ weeding can increase plant height. The spacing of $40 \mathrm{~cm} \times 40 \mathrm{~cm}$ can reduce the population and dry weight of broadleaf weeds. The planting distance of $40 \mathrm{~cm} \times 30 \mathrm{~cm}$ can increase the fresh weight of pods, pod weight/plot, and the highest dry weight of pods/ plants. The frequency of weeding $2 x$ can reduce the population and dry weight of broadleaf weeds; whereas weeding frequency $3 \mathrm{x}$ can reduce weed populations of grass and sedges- weeds, and dry weight of broadleaf weeds. The $3 \mathrm{x}$ weeding frequency can also increase the total number of pods/plants, pod weight/plot, and pod weight/plant.
\end{abstract}

Keyword: peanut, frequency of weeding, spacing, weed population

\begin{abstract}
ABSTRAK
Penelitian ini bertujuan untuk menentukan jarak tanam dan frekuensi penyiangan yang memberikan pertumbuhan dan hasil tertinggi kacang tanah. Tanaman kacang tanah ditanam di Lahan Percobaan Fakultas Pertanian, Universitas Bengkulu pada bulan Oktober sampai Desember 2018. Penelitian menggunakan Rancangan Acak Kelompok Lengkap (RAKL) dengan 2 faktor dan 3 ulangan. Faktor pertama yaitu jarak tanam terdiri atas $40 \mathrm{~cm}$ x $20 \mathrm{~cm} ; 40 \mathrm{~cm}$ x 30 $\mathrm{cm}$;dan $40 \mathrm{~cm}$ x $40 \mathrm{~cm}$. Faktor kedua yaitu frekuensi penyiangan terdiri atas tanpa penyiangan, 1x penyiangan (umur 2_MST), 2x penyiangan (2 dan 4 MST), dan 3x penyiangan (2, 4,dan 6 MST). Hasil penelitian menunjukkan bahwa interaksi antara jarak tanam $40 \mathrm{~cm} \times 40 \mathrm{~cm}$ dan 2 x penyiangan dapat meningkatkan tinggi tanaman. Jarak tanam 40 $\mathrm{cm}$ x 40 cm_dapat_menurunkan_populasi gulma daun lebar_dan_bobot kering gulma daun lebar. Jarak tanam $40 \mathrm{~cm} \times$ $30 \mathrm{~cm}$ dapat meningkatkan bobot segar polong, bobot polong/petak, dan bobot polong kering/tanaman tertinggi. Frekuensi penyiangan $2 \mathrm{x}$ dapat menurunkan populasi gulma daun lebar dan bobot kering gulma daun lebar; sedangkan frekuensi penyiangan $3 \mathrm{x}$ dapat_menurunkan populasi gulma rerumputan, populasi gulma teki, dan_bobot gulma rerumputan._Frekuensi penyiangan sebanyak 3x juga dapat meningkatkan jumlah polong total/tanaman, bobot polong/petak, dan bobot kering polong/tanaman.
\end{abstract}

Kata kunci: frekuensi penyiangan, jarak tanam, kacang tanah, populasi gulma 


\section{PENDAHULUAN}

Peningkatan produksi tanaman kacang tanah ini memiliki kendala yang sangat besar berupa pengolahan tanah yang belum optimal, serangan hama dan penyakit, penanaman varietas berproduksi rendah, penggunaan benih yang rendah, dan kekeringan. Kendala tersebut dapat diatasi dengan melakukan berbagai usaha seperti perbaikan cara bertanam, penggunaan varietas unggul, pengaturan populasi tanaman, pemakaian pupuk dan penggunaan zat pengatur tumbuh dengan jenis dosis tepat dan pengendalian OPT.

Rendahnya hasil kacang tanah dapat juga_disebabkan oleh kehadiran gulma. Terdapat interaksi antara jenis dan kerapatan gulma dalam mempengaruhi tinggi tanaman, bobot polong segar, bobot polong kering/petak dan bobot 100 butir kacang tanah (Erliyana et al., 2015). Gulma yang dibiarkan tumbuh pada tanaman kacang tanah dapat menurunkan hasil sampai dengan 50\% (Moenandir, 1993). Hasil penelitian Murrinie (2004) pada pertanaman kacang tanah di Pati menunjukkan bahwa keberadaan gulma dapat menurunkan bobot polong segar/tanaman sebesar 34,8\%, bobot polong kering/tanaman 37,4\%, bobot biji/tanaman $30,8 \%$, bobot polong segar/ hektar 36,6\%, bobot polong kering/hektar 32,3\% dan bobot biji/hektar sebesar 30,4\%. Oleh karena itu pengendalian gulma harus dilakukan agar pertumbuhan dan hasil tanaman meningkat.

Pengendalian gulma secara efektif dan efisien pada pertanaman kacang tanah dapat dilakukan dengan menerapkan teknik-teknik budidaya dan sedapat mungkin meminimalkan penggunaan bahan kimia yang menyebabkan kerusakan lingkungan. Salah satu cara yang banyak dilakukan ialah dengan melakukan penyiangan karena mudah dan murah, selain itu juga ramah lingkungan. Efektivitas penyiangan sangat ditentukan oleh ketepatan dalam menetapkan waktu pelaksanaannya. Tanaman budidaya yang bebas gulma bebas gulma selama periode kritisnya diharapkan tidak terganggu produktivitasnya (Moenandir, 1993).

Selain penyiangan, pengaturan jarak tanam juga merupakan cara pengendalian gulma secara kultur teknis yang dapat meningkatkan daya saing tanaman terhadap gulma dan meningkatkan hasil. Peningkatan kerapatan populasi tanaman/satuan luas pada suatu batas tertentu dapat meningkatkan hasil tanaman (Mintarsih et al., 1989). Namun penambahan jumlah tanaman selanjutnya akan menurunkan hasil karena terjadi kompetisi unsur hara, air, dan_cahaya matahari. Faktor utama yang menyebabkan turunnya hasil adalah daun yang saling menutup.

Cahaya matahari merupakan faktor penting dalam proses fotosintesis dan penentu laju pertumbuhan tanaman (LPT) sehingga intensitas, lama penyinaran dan kualitasnya sangat berpengaruh terhadap proses fotosintesis. Daun yang saling menutupi menyebabkan cahaya tidak dapat diteruskan pada daun bagian bawah sehingga fotosintesis tidak optimal, yang dapat menyebabkan penurunan hasil.

Penentuan jarak tanam dipengaruhi oleh_ varietas yang ditanam, pola tanam, kesuburan tanah, dan bagian tanaman yang akan digunakan sebagai pendekatan ekonomi. Jarak tanam yang tidak teratur akan mengakibatkan terjadinya kompetisi baik terhadap cahaya matahari, air, maupun unsur hara. Jarak tanam yang rapat mengakibatkan proses penyerapan unsur hara menjadi kurang efesien, karena kondisi perakaran di dalam tanah yang saling bertaut sehingga kompetisi antar tanaman dalam mendapatkan unsur hara menjadi lebih besar. Pengaturan jarak tanam pada suatu areal tanah pertanian merupakan salah satu cara yang berpengaruh terhadap hasil yang akan dicapai. Makin rapat jarak tanam menyebabkan lebih banyak tanaman yang tidak berbuah. Jarak tanam juga mempengaruhi persaingan antar tanaman dalam mendapatkan air dan unsur hara, sehingga akan mempengaruhi hasil (Harjadi, 2002). Penentuan jarak tanam tergantung pada daya tumbuh benih, kesuburan tanah, musim dan varietas yang ditanam. Benih dapat ditanam pada jarak tanam yang lebih rapat apabila daya tumbuh benih agak rendah, pada tanah yang tandus, varietas yang batangnya tidak panjang dan penanaman pada musim kemarau, sedangkan benih dapat ditanam pada jarak tanam yang lebih renggang apabila ditanam pada tanah yang subur dan varietas yang banyak bercabang (Murinnie, 2007).

Pada tanah yang subur, benih kacang tanah ditanam dalam larikan dengan jarak tanam $40 \mathrm{~cm} \times$ $15 \mathrm{~cm}$ atau $30 \mathrm{~cm}$ x $20 \mathrm{~cm}$. Pada tanah yang kurang subur dapat ditanam lebih rapat yaitu $40 \mathrm{~cm} \times 10 \mathrm{~cm}$ atau $20 \mathrm{~cm}$ x $20 \mathrm{~cm}$ (Suprapto, 2004). Semakin lebar jarak tanam dalam baris kacang tanah, jumlah polong isi/tanaman makin banyak. Jumlah polong isi terbanyak dicapai pada jarak tanam $40 \mathrm{~cm} \times 30 \mathrm{~cm}$, dan jumlah polong isi paling sedikit dihasilkan pada jarak tanam $40 \mathrm{~cm}$ x15 cm (Kadekoh, 2007). Selanjutnya, perlakuan jarak tanam $20 \mathrm{~cm}$ x $30 \mathrm{~cm}$ dengan ukuran plot $2,8 \mathrm{~m} \times 1,6 \mathrm{~m}$ berpengaruh nyata terhadap pertumbuhan dan hasil kacang tanah yaitu 530,842 g polong kering atau $384,833 \mathrm{~g}$ biji kering/ plot, sedangkan terendah pada jarak tanam $20 \mathrm{~cm}$ x $20 \mathrm{~cm}$ yaitu $421,608 \mathrm{~g}$ polong kering atau $313,05 \mathrm{~g}$ biji kering/plot.

Keuntungan menggunakan jarak tanam rapat antara lain: benih yang tidak tumbuh atau bila ada tanaman muda yang mati dapat terkompensasi sehingga tanaman tidak terlalu jarang, permukaan tanah dapat segera tertutup sehingga pertumbuhan gulma dapat ditekan dan jumlah tanaman yang tinggi diharapkan dapat memberikan hasil yang tinggi pula. Sebaliknya jarak tanam yang terlalu rapat mempunyai beberapa kerugian, yaitu: polong/ tanaman berkurang sehingga 
hasil/hektar menjadi rendah, ruas batang tumbuh menjadi lebih panjang sehingga tanaman kurang kokoh dan mudah roboh, benih yang dibutuhkan lebih banyak, dan penyiangan sukar dilakukan (Suprapto, 2004). Jarak tanam yang dianjurkan pada kacang tanah bervariasi mulai dari $40 \mathrm{~cm} \mathrm{x} 10 \mathrm{~cm}, 40 \mathrm{~cm} \mathrm{x}$ $15 \mathrm{~cm}, 40 \mathrm{~cm} \times 20 \mathrm{~cm}, 30 \mathrm{~cm} \times 20 \mathrm{~cm}, 30 \mathrm{~cm} \times 15$ $\mathrm{cm}$ atau $20 \mathrm{~cm} \times 20 \mathrm{~cm}$. Jumlah biji yang ditanam per lubang bervariasi satu atau dua biji/lubang.

Penelitian ini bertujuan untuk mendapatkan jarak tanam dan frekuensi penyiangan yang dapat memberikan pertumbuhan dan hasil kacang tanah yang tertinggi, serta pengaruhnya terhadap populasi gulma.

\section{METODE PENELITIAN}

Penelitian ini dilaksanakan pada bulan Oktober 2018 sampai Januari 2019 di lahan percobaan Medan Baru Kelurahan Kandang Limun, Kecamatan Muara Bangkahulu. Penelitian menggunakan Rancangan Acak Kelompok (RAK) yang disusun secara faktorial, dengan 2 faktor dan 3 ulangan. Faktor pertama adalah jarak tanam terdiri atas $40 \mathrm{~cm} \times 20 \mathrm{~cm} ; 40 \mathrm{~cm}$ x $30 \mathrm{~cm}$; dan $40 \mathrm{~cm}$ x $40 \mathrm{~cm}$. Faktor kedua adalah frekuensi penyiangan terdiri atas penyiangan 0 (tanpa penyiangan); penyiangan $1 \mathrm{x}$ (umur $2 \mathrm{MST}$ ); penyiangan 2x (umur 2 dan 4 MST) dan penyiangan 3x (umur 2, 4, dan 6 MST).

Bahan yang digunakan dalam penelitian ini ialah benih kacang tanah yang berasal dari Balai Penelitian Tanaman Aneka Kacang dan Umbi (BalitKabi), pupuk urea, SP-36. KCl, dan air. Alat yang digunakan ialah timbangan analitik, mistar, tugal kayu, cangkul, dan oven.

Tahapan penelitian yang dilakukan meliputi persiapan lahan, penanaman, pemeliharaan, dan pemanenan. Tanah diolah/digemburkan secara manual dengan menggunakan cangkul sedalam $15 \mathrm{~cm}-20 \mathrm{~cm}$, dan dibersihkan dari sisa tanaman dan gulma. Petakan yang digunakan berukuran $2 \mathrm{~m}$ x 2,4 m. Penanaman dilakukan dengan cara membuat lubang tanam pada media sedalam 3-5 cm, kemudian dimasukkan 1 benih dan diberi insektisida 8-10 butir/lubang dan ditutup dengan rapi. Pemeliharaan tanaman yaitu penyiraman, pemupukan, dan pengendalian hama penyakit. Pengairan dilakukan satu kali sehari, dilakukan pada pagi atau sore hari sehingga tanaman tidak mengalami kekeringan. Penyiangan dilakukan secara manual dengan mencabut gulma yang tumbuh di antara pertanaman, waktu penyiangan sesuai dengan perlakuan yaitu pada saat tanaman berumur $2 \mathrm{mst}, 4 \mathrm{mst}$, dan 6 mst. Pemupukan dilakukan pada saat tanam dan pupuk yang digunakan adalah pupuk Urea $50 \mathrm{~kg} / \mathrm{ha}$ (24 g/petak ), SP36 75 $\mathrm{kg} / \mathrm{ha}$ (36 g/petak), dan $\mathrm{KCl} 50 \mathrm{~kg} / \mathrm{ha}(24 \mathrm{~g} /$ petak). Pemupukan dilakukan dengan membuat lubang pada jarak $5 \mathrm{~cm}$ dari tanaman kacang tanah kemudian pupuk dibenamkan dan ditutup (Adisarwanto, 2008).
Pemanenan dilakukan pada hari ke-90 dan hari ke-93 saat kondisi daun tanaman kacang tanah masih hijau.

Pengamatan dilakukan pada 5 tanaman sampel untuk setiap petak percobaan. Tanaman sampel ditentukan secara acak pada tanaman yang berada di tengah petakan. Variabel yang diamati pada penelitian terdiri atas variabel gulma dan variabel tanaman kacang tanah. Data dari variabel yang diamati dianalisis secara statistik dengan menggunakan sidik ragam pada taraf 5\%. Duncan't Multipe Range Test (DMRT) pada taraf 5\% dilakukan untuk membandingkan rata-rata antar perlakuan (Freund \& Wilson, 2003).

\section{HASIL DAN PEMBAHASAN}

Hasil sidik ragam menunjukkan bahwa ada interaksi antara jarak tanam dengan waktu penyiangan terhadap tinggi tanaman kacang tanah umur 8 MST. Jarak tanam secara mandiri berpengaruh terhadap populasi gulma daun lebar, bobot gulma daun lebar, populasi total gulma, tinggi tanaman bobot polong segar/tanaman, bobot polong segar/petak, dan bobot polong kering/tanaman. Sedangkan faktor frekuensi penyiangan secara mandiri berpengaruh terhadap tinggi tanaman, populasi gulma daun lebar, populasi gulma daun sempit, populasi gulma teki, populasi total gulma, bobot gulma daun sempit, bobot kering gulma daun lebar, bobot kering gulma teki, bobot kering total gulma, jumlah polong total, dan bobot polong/petak, dan bobot polong kering/tanaman.

Rata-rata populasi gulma daun lebar, populasi gulma total, dan bobot gulma berdaun lebar terendah dijumpai pada perlakuan jarak tanam $40 \mathrm{~cm}$ x $40 \mathrm{~cm}$ (Tabel 1).

Tabel 1. Rata-rata populasi gulma dan bobot gulma pada setiap jarak tanam

\begin{tabular}{l|ccc}
\hline Jarak Tanam & $\begin{array}{c}\text { Populasi Gulma Daun } \\
\text { Lebar (batang } / 0.25 \mathrm{~m}^{2)}\end{array}$ & $\begin{array}{c}\text { Populasi Gulma } \\
\left.\text { Total (batang } / 0.25 \mathrm{~m}^{2}\right)\end{array}$ & $\begin{array}{c}\text { Bobot Gulma Daun } \\
\text { Lebar }\left(\mathrm{g} / 0.25 \mathrm{~m}^{2}\right.\end{array}$ \\
\hline $40 \mathrm{~cm} \times 20 \mathrm{~cm}$ & $8,75 \mathrm{~b}$ & $20,92 \mathrm{ab}$ & $18,31 \mathrm{~b}$ \\
\hline $40 \mathrm{~cm} \times 30 \mathrm{~cm}$ & $10,42 \mathrm{a}$ & $21,58 \mathrm{a}$ & $20,82 \mathrm{a}$ \\
\hline $40 \mathrm{~cm} \times 40 \mathrm{~cm}$ & $8,42 \mathrm{~b}$ & $19,42 \mathrm{~b}$ & $17,57 \mathrm{~b}$ \\
\hline Keterangan : Angka-angka yang diikuti oleh huruf yang sama pada kolom yang sama
\end{tabular}

berbeda tidak nyata pada DMRT $5 \%$

Penggunaan jarak tanam $40 \mathrm{~cm}$ x $40 \mathrm{~cm}$ merupakan jarak tanam tepat dalam menekan pertumbuhan gulma daun lebar. Penggunaan jarak tanam yang tepat dapat menekan pertumbuhan gulma . Pada dasarnya pemakaian jarak tanam yang rapat bertujuan untuk meningkatkan hasil, asalkan faktor pembatas dapat dihindari sehingga tidak terjadi persaingan antar tanaman. Pengaturan jarak tanam yang tepat juga bermanfaat untuk menekan pertumbuhan gulma, karena pertumbuhan tajuk dapat dengan cepat menutupi permukaan tanah. Bila jarak tanam atau jarak antar baris tanaman terlalu lebar akan memberikan kesempatan kepada gulma untuk dapat tumbuh dengan baik. 
Jarak tanam $40 \mathrm{~cm} \times 30 \mathrm{~cm}$ menghasilkan bobot polong segar/tanaman, bobot polong kering/ tanaman, dan bobot polong/petak tertinggi (Tabel 2). Hal ini diduga karena pada jarak tanam $40 \mathrm{~cm} \times 30$ $\mathrm{cm}$ persaingan antar tanaman maupun dengan gulma dalam mendapatkan unsur hara dan air lebih rendah dari pada jarak tanam lainnya.

Tabel 2. Rata-rata hasil kacang tanah pada setiap jarak tanam

\begin{tabular}{l|ccc}
\hline Jarak Tanam & $\begin{array}{c}\text { Bobot Polong } \\
\text { Segar/Tanaman }(\mathrm{g})\end{array}$ & $\begin{array}{c}\text { Bobot Polong Kering / } \\
\text { Tanaman }(\mathrm{g})\end{array}$ & $\begin{array}{c}\text { Bobot Polong } \\
\text { Petak (kg) }\end{array}$ \\
\hline $40 \mathrm{~cm} \times 20 \mathrm{~cm}$ & $44,11 \mathrm{~b}$ & $27,03 \mathrm{~b}$ & $2,11 \mathrm{~b}$ \\
\hline $40 \mathrm{~cm} \times 30 \mathrm{~cm}$ & $55,24 \mathrm{a}$ & $28,39 \mathrm{a}$ & $2,52 \mathrm{a}$ \\
\hline $40 \mathrm{~cm} \times 40 \mathrm{~cm}$ & $50,40 \mathrm{ab}$ & $28,05 \mathrm{a}$ & $2,18 \mathrm{~b}$ \\
\hline
\end{tabular}

Keterangan : Angka-angka yang diikuti oleh huruf yang sama pada kolom yang sama berbeda tida nyata pada DMRT $5 \%$

Kerapatan tanaman mempunyai hubungan yang tidak dapat dipisahkan dengan hasil yang tercermin pada jarak tanam antar barisan dan dalam barisan tanaman (Susilowati, 2011). Jarak tanam yang lebar akan memberikan ruang tumbuh kacang tanah semakin lebar, sehingga persaingan antar tanaman dalam mendapatkan cahaya matahari, air, dan unsur hara menjadi lebih kecil (Hidayat, 2008). Semakin lebar jarak tanam maka tajuk tanaman tidak saling menutupi satu sama lain dalam mendapatkan cahaya matahari sehingga indeks luas daun menjadi lebih tinggi (Lestari et al., 2019). Namun demikian, penggunaan jarak tanam terlalu lebar akan mengurangi populasi tanaman sehingga berpotensi menurunkan hasil tanaman. Sedangkan penggunaan jarak tanaman terlalu sempit juga berpotensi menurunkan hasil tanaman. Pada jarak tanam yang sempit terjadi persaingan antar tanaman dalam mendapatkan unsur hara, sinar matahari dan air sehingga dapat memacu tanaman untuk tumbuh dan memungkinkan pertumbuhan dan perkembangan tanaman menjadi maksimal (Utomo et al., 2017). Jarak tanam yang terlalu sempit mungkin tanaman budidaya akan memberikan hasil yang relatif kurang karena adanya kompetisi antar tanaman itu sendiri (Mayadewi, 2007). Populasi tanaman yang terlalu tinggi akan menyebabkan daun cepat saling menutupi. Bila daun saling menutupi maka cahaya tidak dapat diteruskan pada daun bagian bawah sehingga fotosintesis tidak optimal sehingga mempengaruhi pembentukan polong dan organ tanaman lainnya (Herawati et al., 2014).

Jarak tanam $40 \mathrm{~cm} \times 30 \mathrm{~cm}$ menghasilkan bobot polong kering/tanaman tertinggi. Hasil penelitian ini mengindikasikan bahwa jarak tanam $40 \mathrm{~cm}$ x $30 \mathrm{~cm}$ merupakan jarak tanam terbaik untuk tanaman kacang tanah sehingga menghasilkan bobot polong kering/ tanaman tertinggi. Jarak tanaman yang baik, akan mendukung tanaman tumbuh dan berkembang dengan lebih baik. Selain itu, tingginya bobot polong kering/ tanaman pada jarak tanam $40 \mathrm{~cm}$ x $30 \mathrm{~cm}$ dikarenakan pada jarak tanam tersebut menghasilkan bobot polong segar/tanaman tertinggi. Cahaya matahari merupakan faktor penting dalam proses fotosintesis dan penentu laju pertumbuhan tanaman (LPT), khususnya intensitas, lama penyinaran, dan kualitas penyinaran. Hasil fotosintesis yang optimal akan digunakan dalam pembentukan polong dan berbagai bagian penting dari tanaman. Jarak tanam berpengaruh terhadap intensitas cahaya matahari (Djukri, 2005). Jarak tanam renggang menyebabkan laju fotosintesis yang diterima tanaman merangsang pembentukan daun, cabang, peningkatan bobot kering tanaman, nisbah akar tajuk dan diikuti oleh peningkatan hasil (Pangli, 2014).

Bobot polong kering/petak berkorelasi positif dengan bobot biji/petak. Hal ini berarti semakin besar bobot polong basah dan kering/petak akan semakin besar pula bobot biji yang dihasilkan (Rahmawati et al., 2016). Hal ini terbukti dari hasil penelitian yang menunjukkan bahwa penggunaan jarak tanam $40 \mathrm{~cm}$ x $30 \mathrm{~cm}$ menghasilkan bobot polong segar dan kering/tanaman lebih tinggi dari pada perlakuan lainnya. Secara umum hasil penelitian menunjukkan bahwa walaupun jarak tanam $40 \mathrm{~cm}$ x $30 \mathrm{~cm}$ menghasilkan populasi dan bobot kering gulma lebih tinggi dari pada jarak tanam $40 \mathrm{~cm} \times 20 \mathrm{~cm}$ dan $40 \mathrm{~cm} \times 40 \mathrm{~cm}$, namun menghasilkan komponen hasil lebih tinggi. Hal ini diduga karena walaupun terdapat gulma yang tumbuh namun suplai nutrisi terhadap tanaman tetap berjalan dengan baik, sehingga keberadaan gulma tidak mengganggu tanaman. Hasil penelitian Kilkoda (2017) juga menunjukkan bahwa pengaruh pengendalian gulma pada perlakuan penyiangan selamanya atau bersih gulma berbeda tidak nyata dengan perlakuan penyiangan gulma selama 6 minggu. Faktor penguasaan ruang tumbuh, cahaya, dan unsur hara tersedia dengan baik, sehingga jumlah hasil dari fotosintat yang diproduksi oleh tanaman dengan sendirinya meningkat.

Populasi gulma berdaun lebar, populasi gulma daun rumput-rumputan populasi gulma total, bobot kering gulma daun lebar, dan bobot kering gulma rerumputan terendah dijumpai pada frekuensi penyiangan 2 atau 3 kali (Tabel 3). Hal ini dapat terjadi karena semakin tinggi frekuensi penyiangan maka akan semakin sedikit pula jumlah gulma yang tumbuh pada areal budidaya. Penyiangan gulma yang sempurna akan menghambat keberadaan gulma sebagai kompetitor hara bagi tanaman (Sukman \& Yakup, 1995). Penundaan penyiangan sampai gulma berbunga menyebabkan pembongkaran akar gulma tidak maksimum dan gagal mencegah tumbuhnya biji-biji gulma yang viable sehingga memberi kesempatan untuk perkembangbiakan dan penyebarannya.

Hasil penelitian Lailiyah et al. (2014); Latifa et al. (2015); dan Prayogo et al. (2017) menunjukkan 
bahwa penyiangan gulma mampu menekan pertumbuhan serta bobot kering gulma. Pengendalian gulma secara mekanis dapat menekan pertumbuhan gulma dengan cara merusak bagian tanaman hingga gulma tersebut mati atau pertumbuhan terhambat (Sebayang, 2004).

Tabel 3. Rata-rata populasi gulma pada frekuensi penyiangan

\begin{tabular}{|c|c|c|c|c|c|c|}
\hline $\begin{array}{c}\text { Frekuensi Penyiangan } \\
\text { (kali) } \\
\end{array}$ & PGDL & PGDS & PGTotal & PGT & BKGDL (g) & BKGDS $(\mathrm{g})$ \\
\hline 0 & $11,00 \mathrm{a}$ & $7,11 \mathrm{a}$ & $6,22 \mathrm{a}$ & $24,33 \mathrm{a}$ & $22,18 \mathrm{a}$ & $15,73 \mathrm{a}$ \\
\hline 1 & $9,89 \mathrm{a}$ & $6,00 \mathrm{~b}$ & $5,22 \mathrm{~b}$ & $21,11 \mathrm{~b}$ & $20,11 \mathrm{a}$ & $14,68 \mathrm{~b}$ \\
\hline 2 & $7,78 \mathrm{~b}$ & $5,67 \mathrm{~b}$ & $5,11 \mathrm{~b}$ & $18,56 \mathrm{c}$ & $16,32 \mathrm{~b}$ & $14,28 \mathrm{bc}$ \\
\hline 3 & $8,11 \mathrm{~b}$ & $5,33 \mathrm{~b}$ & $5,10 \mathrm{~b}$ & $18,54 \mathrm{c}$ & $16,98 \mathrm{~b}$ & $13,83 \mathrm{c}$ \\
\hline
\end{tabular}

Keterangan : Angka-angka yang diikuti oleh huruf yang sama pada kolom yang sama berbeda tidak nyata pada DMRT 5\%. PGDL = Populasi Gulma Daun Lebar, PGDS = Populasi Gulma Daun Sempit PG = Populasi Gulma; PGT = Populasi Gulma Teki, BKGDL = Bobot Kering Gulma Daun Lebar BKGDS = Bobot Kering Gulma Daun Sempit

Rendahnya bobot kering gulma diakibatkan tersiangnya gulma dan terbuangnya bagian-bagian vegetatif gulma sehingga potensi gulma untuk tumbuh makin berkurang (Akbar, 2012).

Jumlah polong total/tanaman, bobot polong kering/ tanaman, dan bobot polong/petak terbanyak dihasilkan oleh 3 x penyiangan (Tabel 4). Rendahnya populasi gulma pada penyiangan yang dilakukan sebanyak $3 \mathrm{x}$ menyebabkan tanaman lebih banyak menyerap unsur hara dan air serta lebih tinggi menerima sinar matahari sehingga pertumbuhan dan hasil tanaman lebih baik.

Gulma yang tumbuh bersama tanaman dapat mengurangi kualitas dan kuantitas hasil tanaman karena gulma menjadi pesaing dalam pengambilan unsur hara, air dan cahaya serta menjadi inang hama dan penyakit. Hal ini menyebabkan gangguan dari gulma terhadap tanaman pokok perihal kompetisi faktor-faktor tumbuh menjadi kecil sehingga pada fase generatif selanjutnya yaitu pembentukan polong dan biji menjadi lebih tinggi dari pada tanaman yang tidak dilakukan penyiangan pada waktu tersebut (Fitriana, 2008). Kehadiran gulma pada pertanaman kacang tanah merupakan salah satu penyebab rendahnya hasil kacang tanah. Pengaruh gulma terhadap tanaman dapat terjadi secara langsung yaitu dalam hal bersaing untuk mendapatkan unsur hara, air, cahaya dan ruang tumbuh. Secara tidak langsung sejumlah gulma merupakan inang dari hama dan penyakit. Gulma yang dibiarkan tumbuh pada tanaman kacang tanah dapat menurunkan hasil sampai dengan 47\% (Moenandir, 1993).

Hasil penelitian ini juga mengindikasikan bahwa semakin tinggi frekuensi penyiangan akan diikuti dengan bertambahnya bobot polong kering/tanaman. Hal ini karena frekuensi penyiangan yang dilakukan kurang dari $3 \mathrm{x}$ akan tumbuh gulma lebih banyak sehingga gangguan terhadap tanaman lebih tinggi. Menurut Keberadaan gulma dalam jumlah yang cukup banyak dan rapat selama masa pertumbuhan dan perkembangan akan menyebabkan kehilangan hasil secara total (Alfandi \& Dukat, 2007).
Tabel 4. Rata-rata hasil kacang tanah pada setiap frekuensi penyiangan

\begin{tabular}{|c|c|c|c|}
\hline $\begin{array}{c}\text { Frekuensi Penyiangan } \\
\text { (kali) }\end{array}$ & $\begin{array}{c}\text { Jumlah Polong } \\
\text { Total/Tanaman (polong) }\end{array}$ & $\begin{array}{c}\text { Bobot Polong } \\
\text { Kering/Tanaman (g) }\end{array}$ & $\begin{array}{c}\text { Bobot } \\
\text { Polong/Petak (kg) }\end{array}$ \\
\hline 0 & $14,84 \mathrm{c}$ & $27,60 \mathrm{~b}$ & $1,96 \mathrm{c}$ \\
\hline 1 & $15,27 \mathrm{bc}$ & $27,24 \mathrm{~b}$ & $2,12 \mathrm{bc}$ \\
\hline 2 & $15,89 \mathrm{ab}$ & $27,99 \mathrm{ab}$ & $2,36 \mathrm{ab}$ \\
\hline 3 & $16,56 \mathrm{a}$ & $28,47 \mathrm{a}$ & $2,64 \mathrm{a}$ \\
\hline Keterangan : Angka-angka yang diikuti oleh huruf yang sama pada kolom yang sama berbeda
\end{tabular}
tidak nyata pada DMRT $5 \%$.

Kehadiran gulma pada pertanaman akan menimbulkan kompetisi yang sangat serius dalam mendapatkan air, hara, dan cahaya matahari, dampaknya hasil tanaman tidak mampu menunjukkan potensi yang sebenarnya (Kilkoda et al., 2015). Besarnya penurunan hasil biji kacang tanah berkaitan erat dengan berkurangnya jumlah polong dan bobot kering polong/ tanaman masing-masing disebabkan karena terjadi persaingan antara tanaman dengan gulma akibat densitas gulma yang begitu tinggi akibat tidak disiang (Hasanudin et al., 2012).

Keberadaan gulma pada budidaya tanaman dapat mengurangi kemampuan tanaman untuk berproduksi. Persaingan atau kompetisi antara gulma dan tanaman yang diusahakan terjadi dalam hal penyerapan unsur-unsur hara dan air dari dalam tanah, penerimaan cahaya matahari untuk proses fotosintesis, dan ruang untuk tumbuh. Selain itu gulma seringkali menimbulkan kerugian-kerugian dalam produksi baik kualitas dan kuantitas, bahkan beberapa gulma dapat menjadi inang bagi hama dan penyakit tanaman (Dinarto \& Astriani, 2012). Penyiangan dapat menekan pertumbuhan gulma yang menjadi pesaing bagi tanaman dalam pengambilan unsur hara, air, cahaya dan ruang tumbuh (Ridwan, 1997).

Pada peubah tinggi tanaman, terlihat ada interaksi antara frekuensi penyiangan dan jarak tanam. Jarak tanam $40 \mathrm{~cm} \times 20 \mathrm{~cm}$ dan penyiangan satu kali dapat meningkatkan tinggi tanaman kacang tanah. Pada jarak tanam $40 \mathrm{~cm}$ x $40 \mathrm{~cm}$ tanaman kacang tanah paling tinggi jika disiangi 2 kali.

Tabel 5. Interaksi antara jarak tanam dan frekuensi penyiangan terhadap tinggi tanaman

\begin{tabular}{|c|c|c|c|c|}
\hline \multirow{2}{*}{$\begin{array}{c}\text { Jarak tanam } \\
\text { kacang tanah }\end{array}$} & \multicolumn{4}{|c|}{ Frekuensi penyiangan (kali) } \\
\hline & 0 & 1 & 2 & 3 \\
\hline \multirow{2}{*}{$40 \mathrm{~cm} \times 20 \mathrm{~cm}$} & $26,60 \mathrm{~b}$ & $31,81 \mathrm{a}$ & $31,33 \mathrm{a}$ & $33,45 \mathrm{a}$ \\
\hline & B & A & A & A \\
\hline \multirow{2}{*}{$40 \mathrm{~cm} \times 30 \mathrm{~cm}$} & 32,89 a & $32,46 \mathrm{a}$ & $32,43 \mathrm{a}$ & $32,00 \mathrm{a}$ \\
\hline & $\mathrm{A}$ & A & $\mathrm{A}$ & A \\
\hline \multirow{2}{*}{$40 \mathrm{~cm} \mathrm{x} 40 \mathrm{~cm}$} & $31,59 \mathrm{~b}$ & $31,20 \mathrm{~b}$ & $34,57 \mathrm{a}$ & $33,73 \mathrm{a}$ \\
\hline & $\mathrm{AB}$ & $\mathrm{B}$ & $\mathrm{A}$ & $\mathrm{AB}$ \\
\hline \multicolumn{5}{|c|}{ Keterangan : Angka-angka yang diikuti oleh huruf yang sama } \\
\hline \multicolumn{5}{|c|}{ berbeda tidak nyata pada DMRT $5 \%$. Huruf besar dibaca ke arah } \\
\hline \multicolumn{4}{|c|}{ horizontal dan huruf kecil dibaca ke arah vertikal. } & \\
\hline
\end{tabular}


Secara umum hasil penelitian menunjukkan bahwa kombinasi jarak tanam $40 \mathrm{~cm}$ x $40 \mathrm{~cm}$ dan 2 kali penyiangan dapat meningkatkan tinggi tanaman yaitu $34,57 \mathrm{~cm}$. Hal ini diduga karena pada perlakuan tersebut persaingan antar tanaman maupun dengan gulma dalam memperebutkan unsur hara, air, dan cahaya lebih rendah daripada perlakuan kombinasi lainnya (Tabel 5). Ketiadaan persaingan antar tanaman, tanaman dan gulma menyebabkan tanaman maksimal memanfaatkan hara yang tersedia sehingga pertumbuhan berlangsung baik dan menunjukkan daya hasil tinggi (Moenandir, 1993).

\section{KESIMPULAN}

Jarak tanam $40 \mathrm{~cm}$ x $40 \mathrm{~cm}$ dapat menekan populasi gulma daun lebar $(8,42 \mathrm{~g})$ dan bobot kering gulma daun lebar $(17,57 \mathrm{~g})$. Jarak tanam $40 \mathrm{~cm} \times 30$ $\mathrm{cm}$ dapat meningkatkan bobot segar polong $(55,24 \mathrm{~g})$, bobot polong/petak $(2,52 \mathrm{~kg})$, dan bobot polong kering/ tanaman (28,39 g). Penyiangan gulma sebanyak 2 kali dapat menekan populasi gulma daun lebar $(7,78 \mathrm{~g})$, bobot kering gulma daun lebar (16,32 g), sedangkan frekuensi penyiangan 3 kali dapat menekan populasi gulma daun rerumputan $(5,33)$, populasi gulma teki $(5,10 \mathrm{~g})$, dan bobot gulma daun rerumputan $(13,83 \mathrm{~g})$, serta dapat meningkatkan jumlah polong total/ tanaman (16,56 polong), bobot polong/petak $(2,64 \mathrm{~kg})$, dan bobot kering polong/tanaman $(28,47 \mathrm{~g})$. Jarak tanam $40 \mathrm{~cm} \times 40 \mathrm{~cm}$ dengan $2 \mathrm{x}$ penyiangan dapat meningkatkan tinggi tanaman $(34,57 \mathrm{~cm})$.

\section{DAFTAR PUSTAKA}

Adisarwanto, T. (2008). Meningkatkan Produksi Kacang Tanah di Lahan Sawah dan Lahan Kering. Penebar Swadaya, Malang.

Akbar, A. (2012). Pengaruh Sistem Olah Tanah dan Waktu Penyiangan pada Pertumbuhan dan Hasil Kedelai (Glycine max L.) var. Grobogan. Disertasi Doktor. Universitas Brawijaya, Malang.

Alfandi \& Dukat. (2007). Budidaya Kacang-kacangan. Kanisius, Yogyakarta.

Dinarto, W. \& Astriani, D. (2012). Produktivitas kacang tanah di lahan kering pada berbagai intensitas penyiangan. Jurnal AgriSains, 3(4), 33-43.

Djukri. (2005). Efek jarak tanam dan varietas terhadap distribusi cahaya dalam kanopi dan pertumbuhan (biomassa) kedelai. J. Pendidikan Matematika dan Sains, 2(10), 115-121.

Erliyana, E., Sembodo, D.R.J \& Utomo, S.D. (2015). Kompetisi jenis dan kerapatan gulma terhadap pertumbuhan dan produksi kacang tanah (Arachis hypogaea L.) varietas Hypoma 2.J. Agrotek Tropika, 3(3), 321-326. DOI: http://dx.doi.org/ 10.23960/ jat.v3i3.1954.
Fitriana, M. (2008). Pengaruh periode penyiangan gulma terhadap pertumbuhan dan hasil tanaman kacang hijau (Vigna radiata L.) varietas Kenari. Jurnal Agria 5(1), 1-4.

Freund, R. \& Wilson, W. (2003). Statistical Methods. Academic Press., London.

Harjadi, S. S. M. M. (2002). Pengantar Agronomi. Gramedia Pustaka Utama, Jakarta

Hasanuddin, Gina, E. \& Safmaneli. (2012). Pengaruh persaingan gulma Synedrella nodiflora L. Gaertn. pada berbagai densitas terhadap pertumbuhan dan hasil kedelai. Jurnal Agrista.16(2), 146150.

Herawati, N., Sudarto \& Erawati, B.T.R. (2014). Kajian Variasi Jarak Tanam Terhadap Produktivitas Kacang Tanah di Lahan Kering. Prosiding Seminar Hasil Penelitian Tanaman Aneka Kacang dan Umbi. pp. 679-686.

Hidayat, N. (2008). Pertumbuhan dan produksi kacang tanah (Arachis hypogea, L.) varitas lokal Madura pada berbagai jarak tanam. Jurnal Agrovigor, $1(1), 55-64$.

Kadekoh, I. (2007). Komponen hasil dan hasil kacang tanah berbeda jarak tanam dalam sistem tumpangsari dengan jagung yang didefoliasi pada musim kemarau dan musim hujan. Jurnal Agroland. 14(1), 11-17.

Kasno, A. (2007). Produksi padi dan serapan hara N, $\mathrm{P}$, dan $\mathrm{K}$ lahan sawah dengan pupuk majemuk. Akta Agrosia Edisi Khusus, 2, 181-188.

Kilkoda, A.L. (2017). Pengaruh periode pengendalian gulma terhadap komponen hasil 3 varietas kedelai (Glycine Max (L) Merril) berbeda ukuran. Agrosainstek, 1(1), 23-33.

Kilkoda, A.K., Nurmala, T. \& Widayat, D. (2015). Pengaruh keberadaan gulma (Ageratum conyzoides dan Boreria alata) terhadap pertumbuhan dan hasil tiga ukuran varietas kedelai (Glycine $\max \mathrm{L}$. Merr) pada percobaan pot bertingkat. Jurnal Kultivasi, 14(2), 1-8.

Lailiyah, W. N., Widaryanto, E., \& Wicaksono, K. P. (2014). Pengaruh periode penyiangan gulma terhadap pertumbuhan dan hasil tanaman kacang panjang (Vigna sesquipedalis L.). Jurnal Produksi Tanaman, 2(7), 606-612.

Latifa, R. Y., Maghfoer, M. D., \& Widaryanto, E. (2015). Pengaruh pengendalian gulma terhadap tanaman kedelai (Glycine max (L.) Merril) pada sistem olah tanah. Jurnal Produksi Tanaman, 3(4), 311-320.

Lestari, D., Turmudi, E. \& Suryati, D. (2019). Efisiensi pemanfaatan lahan pada sistem tumpangsari dengan berbagai jarak tanam jagung dan varietas kacang hijau. Jurnal Ilmu-Ilmu Pertanian Indonesia, 21(2), 82-90. DOI: https://doi.org/ 10.31186/jipi.21.2.82-90.

Mayadewi. N. N. A. (2007). Pengaruh jenis pupuk 
kandang dan jarak tanam terhadap pertumbuhan gulma dan hasil jagung manis. Jurnal Agritrop, 26(4), 153-159.

Mintarsih, Yulia, E., Hannasih, S. \& Widyatmoko, J. (1989). Pengaruh jarak tanam didalam barisan tanaman terhadap pertumbuhan dan produksi jagung (Zea mays L.) varietas Arjuna. Farming, 313.

Moenandir, J. (1993). Pengantar Ilmu dan Pengendalian Gulma. Rajawali Press., Jakarta.

Murrinie, E. D. 2004. Kajian Variasi Populasi Jagung dan Penyiangan dalam Sistem Tumpang_gilir dengan Kacang Tanah. Tesis. Universitas Gadjah Mada. Yogyakarta.

Murinnie, E.D. (2007). Laporan Penelitian Analisis Pertumbuhan Kacang Tanah dan Pergeseran Komposisi Gulma pada Frekuensi Penyiangan dan Jarak Tanam Yang Berbeda. Fakultas Pertanian Universitas Muria Kudus, Kudus.

Pangli, M. (2014). Pengaruh jarak tanam terhadap pertumbuhan dan hasil kedelai (Glycine max L. Merrill). Jurnal AgroPet., 11(1), 1-8.

Prayogo, D. P., Sebayang, H. T. \& Nugroho, A. (2017). Pengaruh pengendalian gulma pada pertumbuhan dan hasil tanaman kedelai (Glycine max
(L.) Merril) pada berbagai sistem olah tanah. Jurnal Produksi Tanaman, 5(1), 24-32.

Rahmawati A, Purnamawati, H. \& Kusumo, Y.W.E. (2016). Pertumbuhan dan produksi Kacang Bogor (Vigna subterranea (L.) Verdcourt) pada beberapa jarak tanam dan frekuensi pembumbunan. Bul.Agrohorti,4(3), 302-311. DOI: https:// doi.org/10.29244/agrob.4.3.302-311.

Ridwan. (1997). Skala Pengukuran VariabelVariabel Penelitian. Alfabeta, Bandung.

Sebayang, H. T. (2004). Herbisida dan Pengendalian Gulma Tanaman. Fakultas Pertanian Universitas Brawijaya, Malang.

Sukman, Y. \& Yakup. (2002). Gulma dan Teknik Pengendaliannya, Fakultas Pertanian Universitas Sriwijaya, Palembang.

Suprapto. (2004). Bertanam Kacang Tanah. Penebar Swadaya, Jakarta.

Utomo, W., Astiningrum, M. \& Susilowati, Y.E. (2017). Pengaruh mikoriza dan jarak tanam terhadap hasil tanaman jagung manis (Zea mays Var. Saccharata Sturt). Jurnal Ilmu Pertanian Tropika dan Subtropika (Journal of Tropical and Subtropical Agricultural Science, 2(1), 28-33. 